\title{
Gynandromorphs of Megachile picicornis (Morawitz, 1877) and M. deceptoria (Peréz, 1890) (Hymenoptera: Megachilidae) and their evolutionary interpretation
}

\author{
Гинандроморфы Megacbile picicornis (Morawitz, 1877) \\ и M. deceptoria (Peréz, 1890) (Hymenoptera: Megachilidae) \\ и их эволющионная интерпретаџия
}

\author{
A.V. Fateryga ${ }^{1,2}$, S.P. Ivanov ${ }^{2}$, M.A. Filatov ${ }^{3}$ \\ A.В. Фатерыга ${ }^{1,2}$, С.П. Иванов ${ }^{2}$, М.А. Фиматов ${ }^{3}$
}

\begin{abstract}
${ }^{1}$ Nikitskiy Botanical Garden - National Scientific Center, Nikita, Yalta 98648, Ukraine. E-mail: fater_84@list.ru
${ }^{2}$ V.I. Vernadskiy Taurida National University, 4 Academician Vernadskiy Avenue, Simferopol 95007, Ukraine. E-mail: spi2006@list.ru ${ }^{3}$ V.V. Dokuchaev Kharkov National Agrarian University, P.O. Communist-1, bdg. 4, KhNAU Campus, Kharkov Province 62483, Ukraine. E-mail: filatovhnau@gmail.com

${ }^{1}$ Никитский ботанический сад - Национальный научный центр, Никита, Ялта 98648, Украина.

${ }^{2}$ Таврический национальный университет им. В.И. Вернадского, проспект Академика Вернадского, 4, Симферополь 95007 , Украина.

${ }^{3}$ Харьковский национальный аграрный университет им. В.В. Докучаева, п/о Коммунист-1, учебный городок ХНАУ, корпус 4 , Харьковская область 62483, Украина.
\end{abstract}

KEY WORDS: bees, Megachilidae, Megachile, gynandromorphs, evolution of cleptoparasitism.

КЛЮЧЕВЫЕ СЛОВА: пчелы, Megachilidae, Megachile, гинандроморфы, эволюция клептопаразитизма.

ABSTRACT. Seven gynandromorphic specimens of Megachile picicornis and M. deceptoria collected in the Crimea are described. All specimens of both species have similar morphology, i.e. the male-like head (except for the 12-segmented antennae) and legs as well as the female-like metasoma that totally lacks scopa. Arguments in favor of the hypothesis that ontogenetic anomalies of that kind could lead to the origin of cleptoparasitic species of bees from the nest-building ones are given.

РЕЗЮМЕ. Описано семь гинандроморфных экземпляров Megachile picicornis и M. deceptoria, собранных в Крыму. Все экземпляры обоих видов имеют сходную морфологию: голова (за исключением 12-члениковых антенн) и ноги как у самцов, а метасома — как у самок, но полностью лишенная скопы. Приведены аргументы в пользу гипотезы о том, что подобные онтогенетические аномалии могли приводить к возникновению клептопаразитических видов пчел из гнездостроящих видов.

\section{Introduction}

Various sex-related anomalies are relatively more frequent in Megachilidae than in the other families of Apoidea as well as in the other insects in general [Mitchell, 1929; Popov, 1953; Engel, 2007]. Only few of the anomalies described in this family were true (lateral) gynandromorphs belonging to a number of genera (e.g.
[Bischof, Ulrich, 1929; Tumšs, 1970]), but most of them were mosaic and frontal gynandromorphs that belonged to the genus Megachile Latreille, 1802 [Mitchell, 1929; Wcislo et al., 2004].

More than one hundred years ago, Cockerell described a female of the new species, Megachile detersa Cockerell, 1910, with certain male characters, like 13segmented antennae, dense pubescence of clypeus, spines on the fore coxae and bifurcate claws. In this female, ventral surface of the metasoma was bare and had no trace of the scopa [Cockerell, 1910]. Later on, the same author described the genus Androgynella Cockerell, 1911 on the basis of the series of 14 females and one male of the species mentioned above [Cockerell, 1911]. Since normal females of M. detersa were unknown, he suggested that the genus Androgynella had been an early stage of the evolution of cleptoparasitic bees. Michener [1965] considered the name Androgynella invalid because the corresponding genus had been described on the basis of a group of sexually anomalous specimens, and gave this name the status of the junior synonym of the subgenus Eutricharaea Thomson, 1872 of the genus Megachile.

In 2002-2005, we collected seven gynandromorphic specimens of Megachile in the Crimea and found that they were generally very similar to Cockerell's "Androgynella". These specimens belong to two different species, namely, Megachile (Eutricharaea) picicornis (Morawitz, 1877) and Megachile (Eutricharaea) deceptoria (Peréz, 1890). 

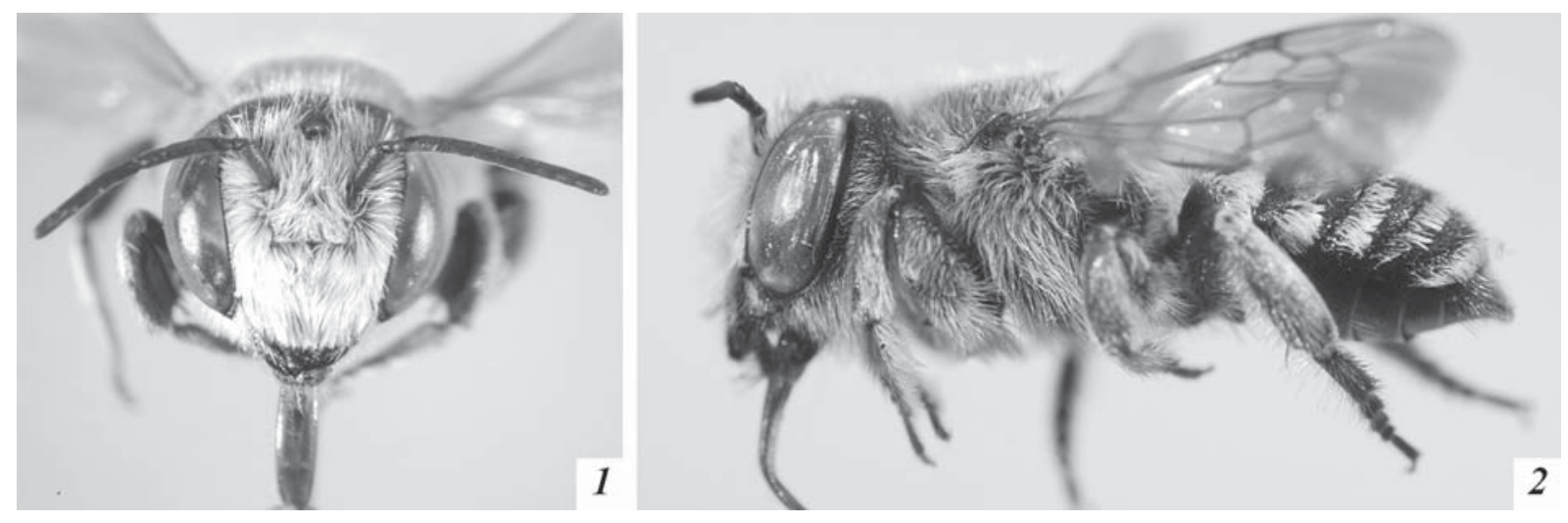

Fig. 1-2. Gynandromorph of Megachile picicornis: 1 - frontal view; 2 - lateral view.

Рис. 1-2. Гинандроморф Megachile picicornis: 1 - вид спереди; 2 - вид сбоку.

\section{Material and methods}

The gynandromorphs were found among the specimens collected by the authors and deposited in the collection of Vernadskiy Taurida National University (Simferopol). The collections of the Zoological Museum of M.V. Lomonosov Moscow State University, Zoological Institute of the Russian Academy of Sciences (St. Petersburg), Institute of Zoology of the National Academy of Sciences of Ukraine (Kiev) and Kharkov Entomological Society were also examined but any gynandromorphic specimens of Megachile from the Crimea were not found. In total, 109 specimens of M. picicornis and 57 specimens of M. deceptoria collected in the Crimea have been studied.

\section{Results}

Six gynandromorphic individuals belonging to M. picicornis were collected, specifically: 1 specimen, Crimea, Karadag Nature Reserve, 01.08.2002 (S.P. Ivanov); 2 specimens, Crimea, Opuk Nature Reserve, 11.08.2003, on Centaurea diffusa (M.A. Filatov); 3 specimens, ibid., 06, 08 and 12.08.2004 (M.A. Filatov). In addition, another specimen belonging to M. deceptoria was also collected: Crimea, Tarhankut Peninsula, Kipchak Gully, 23.06.2005 (A.V. Fateryga).

All specimens of the both species have similar morphology. Specifically, they have a typical male-like head with dense whitish pubescence of the clypeus (Fig. 1). Their mandibles are tridentate with the broad third teeth that is characteristic of the male (normal females have four-toothed mandibles). Nevertheless, the antennae combine both male and female features (Fig. 3): they are 12-segmented as in the female (Fig. 4), but long enough almost like those of the male (Fig. 5). The legs are characteristic of the normal male, with spines on the fore coxae and bifurcate claws. The metasoma is generally female-like except for lack of the
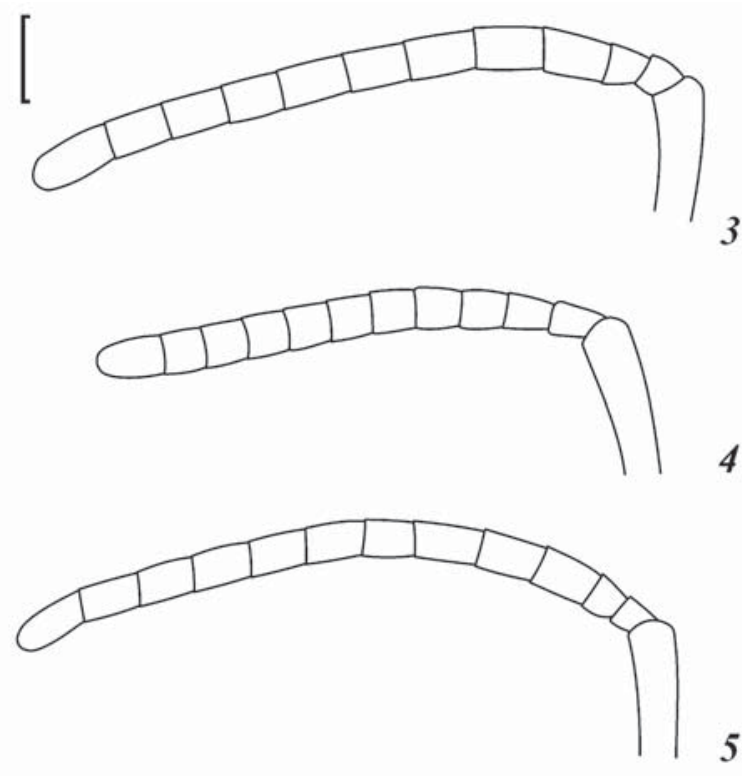

Fig. 3-5. Megachile picicornis: 3 - antennae of gynandromorph; 4 - ditto, normal female; 5 - ditto, normal male. Scale bar $0.5 \mathrm{~mm}$.

Рис. 3-5. Megachile picicornis: 3 - антенны гинандроморфа; 4 - то же, нормальной самки; 5 - то же, нормального самца. Масштаб 0,5 мм.

scopa (Fig. 2). Second to fifth sterna bear only one to three hairs per sternum; moreover, the pubescence is developed only on the first sternum and apical margin of the sixth sternum. Examination of the genitalia confirms that they are indistinguishable from those of the normal female.

We have found deutonymphs of two species of symbiotic mites of the genus Vidia Oudemans, 1905 (Acari, Winterschmidtiidae) on the apical sterna of $M$. deceptoria and on the propodeum of the only specimen of M. picicornis. 


\section{Discussion}

Gynandromorphs of M.picicornis and M. deceptoria are described here for the first time, but similar sexually anomalous specimens are already known in a number of other members of the genus, i.e. in M. detersa [Cockerell, 1910]; M. (Ptilosarus) bertony Schrottky, 1980 [Mitchell, 1929]; M. (Eutricharaea) pilidens Alfken, 1924 [Wolf, 1998a] and M. (Eutricharaea) leachella Curtis, 1828 [Wolf, 1998b]. However, all previously described gynandromorphs can be distinguished from the present ones by their 13-segmented antennae. Nevertheless, one of those gynandromorphs of Megachile (Eutricharaea) subrixator Cockerell, 1915 had 12-segmented antennae ([Cockerell, 1918], quoted in [Mitchell, 1929]). Moreover, Cockerell described two specimens with different numbers of antennal segments (12 and 13). In addition, Mitchell [1941] found a similar gynandromorph of Megachile (Chelostomoides) angelarum Cockerell, 1902 with 12segmented antennae but with the well-developed scopa. Sex-related anomalies of that kind, i.e. combinations of the male-like head and thorax with the femalelike metasoma that lacks the scopa, are therefore quite widespread in Megachile and especially in the subgenus Eutricharaea. It is also noteworthy that we have discovered the very high proportion of gynandromorphs in both $M$. picicornis $(5.5 \%)$ and $M$. deceptoria $(1.8 \%)$ in the Crimea.

We are unaware of any factor inducing the frequent occurrence of gynandromorphs in the genus Megachile. However, it could be explained by masculinization of the females due to the presence of strepsipteran parasites [Popov, 1937]. Moreover, this hypothesis was first put forward by Mitchell [1929] who summarized all data on the sex-related anomalies in Megachile that were available that time. Nevertheless, parasitization by Strepsiptera usually leads to the abnormal development of genitalia. Consequently, we did not considered mites as the possible cause of the above mentioned anomalies because the mites have been found on the normal females and males as well.

In contrast to Mitchell, Cockerell [1911] considered the anomalies described above as an early stage in the evolution of cleptoparasitic bees e.g., Coelioxys Latreille, 1809 and Stelis Panzer, 1806, because females of those taxa had no morphological adaptations for collecting pollen, e.g., the metasomal scopa. According to Wcislo [1999], certain structural features of cleptoparasitic bees that are associated with parasitism could result from the expression of male-like traits in females. The most important of those features that are characteristic of the cleptoparasitic members of different families are: pointed mandibles without teeth, reduction of the pubescence (especially on the legs or on the ventral surface of the metasoma) and relatively long antennae [Wcislo et al., 2004].

The tribe Megachilini consists of the three genera, namely: the nest-building Megachile and the clepto- parasitic Coelioxys and Radoszkowskiana Popov, 1955 [Michener, 2007]. We have examined females of 15 Palaearctic Coelioxys species of the subgenera Allocoelioxys Tkalců, 1974, Boreocoelioxys Mitchell, 1973 and Coelioxys Latreille, 1809, and found some characters which were identical to the male traits of the described gynandromorphs of $M$. picicornis and $M$. deceptoria, i.e. relatively long antennae, tridentate mandibles with the broad third tooth and an incision between the third and the second teeth. In addition, females of one of the examined species, Coelioxys (Allocoelioxys) emarginata Förster, 1853 had entirely bare metasomal sterna. The latter character state has never been found either in the females or males of nest-building species (even in those using specialized structures of their legs to transport the collected pollen), but was characteristic of the described gynandromorphs. Thus cleptoparasitic taxa in Megachilini could originate from the nestbuilding species of Megachile through expression of the male traits in the females via the apparent gynandromorphic stage.

From the formal point of view, the described gynandromorphs of $M$. picicornis and $M$. deceptoria are females, because they have normal female genitalia and the functional sting as well as six metasomal segments and 12-segmented antennae. Only morphological analysis (e.g., that of the characteristic structure of the mandibles and legs of the bees) can demonstrate their gynandromorphic nature. It is obvious that these gynandromorphs are unable either to collect pollen or to build nests because they do not have the scopa, and their mandibles are not adapted to leaf-cutting. Unfortunately, we could not study the degree of ovarian development of those individuals because they were preserved in the collection as dried specimens. But if those specimens had well-developed ovaries, it is tempting to speculate that gynandromorphs of that kind could have been able to deposit their eggs into nest cells of the conspecific females. It is also noteworthy that those gynandromorphs have long antennae, because the males use their characteristic antennae of similar structure to look for the females. On the other hand, females of cleptoparasitic species also have to look for nest-building females, but only in order to find their nests. According to the hypothesis of the origin of cleptoparasites from gynandromorphic individuals of nest-building species, they could therefore more or less easily switch their searching behavior in an appropriate manner.

We would like to point out that we were able to collect several gynandromorphs of the two species just in four consecutive years despite an intensive collecting at those localities for a long time (from 2001 until 2010 at Karadag and Opuk, and from 2003 until 2008 at Tarhankut). Individuals bearing sex-related anomalies of that kind seem to be relatively abundant only during certain periods of time with specific biocoenotic conditions. This assumption is in agreement with Rasnitsyn's [2002] hypothesis of the adaptive compromise, according to which species evolution is facilitat- 
ed by relaxation of the environmental control (e.g., when better adapted and more rapidly developing cleptoparasitic species become less abundant).

\section{ACKNOWLEDGEMENTS}

The authors would like to thank A.A. Khaustov (Nikitskiy Botanical Garden - National Scientific Center, Yalta) for identifying mites and M.Yu. Proshchalykin (Institute of Biology and Soil Science of the Far Eastern Branch of the Russian Academy of Sciences, Vladivostok) for providing certain references.

\section{References}

Bischoff H., Ulrich W. 1929. Über einen Gynander der Mauerbiene (Chalicodoma muraria Retz.) [= Chalicodoma parietinum (Geoffroy, 1785)] nebst einigen Bemerkungen über normale Individuen // Zeitschrift für Morphologie und Ökologie der Tiere. Bd.15. S.213-261.

Cockerell T.D.A. 1910. Descriptions and records of bees. - XXXII // Annals and Magazine of Natural History. Ser.8. Vol.6. P.272284.

Cockerell T.D.A. 1911. Descriptions and records of bees. - XXXV // Annals and Magazine of Natural History. Ser.8. Vol.7. P.310319.

Engel M.S. 2007. A lateral gynandromorph in the bee genus Thyreus and the sting mechanism in the Melectini (Hymenoptera: Apidae) // American Museum Novitates. No.3553. P.1-11.

Michener C.D. 1965. A classification of the bees of the Australian and South Pacific regions // Bulletin of the American Museum of Natural History. Vol.130. P.1-362.

Michener C.D. 2007. The Bees of the World. Second ed. Baltimore: The Johns Hopkins University Press. xvi+953 pp.
Mitchell T.B. 1929. Sex anomalies in the genus Megachile, with descriptions of new species (Hymenoptera: Megachilidae) // Transactions of the American Entomological Society. Vol.54. No.4. P.321-383.

Mitchell T.B. 1941. Some additional intersexes in Megachile (Hymenoptera: Megachilidae) // Pan-Pacific Entomologist. Vol.17. No.4. P.165-168.

Popov V.V. 1937. [Gynandromorphism and the effect of parasitic castration (stylopizaton) in Halictus eurygnathus Blüthgen (Hymenoptera, Apoidea)] // Izvestiya Akademii Nauk SSSR. Division of Mathematical and Natural Sciences. Biological Series. Vol.1937. No.2. P.485-494 [in Russian, with English summary].

Popov V.V. 1953. [Gynandromorph of Megachile saussurei Rad. (Hymenoptera, Megachilidae)] // Entomologicheskoe Obozrenie. Vol.33. P.198-201 [in Russian].

Rasnitsyn A.P. 2002. [Evolutionary process and methodology of systematics] // Trudy Russkogo Entomologicheskogo Obshchestva. Vol.73. P.3-107 [in Russian].

Tumšs V. 1970. Ginandromorfa bite Osmia rufa (L.) (Hymenoptera, Apoidea) // Zooloǵijas Muzeja Raksti. Vol.6. P.41-44.

Wcislo W.T. 1999. Transvestism hypothesis: a cross-sex source of morphological variation for the evolution of parasitism among sweat bees (Hymenoptera: Halictidae) // Annals of the Entomological Society of America. Vol.92. No.2. P.239-242.

Wcislo W.T., Gonzalez V.H., Arneson L. 2004. A review of deviant phenotypes in bees in relation to brood parasitism, and a gynandromorph of Megalopta genalis (Hymenoptera: Halictidae) // Journal of Natural History. Vol.38. No.11. P.14431457.

Wolf H. 1998a. Ein Zwitter von Megachile pilidens Alfken (Hymenoptera, Apidae) // Linzer Biologische Beiträge. Bd.30. H.1. S.245.

Wolf H. 1998b. Ein Zwitter von cf. Megachile leachella Curtis (Hymenoptera, Apidae) // Linzer Biologische Beiträge. Bd.30. H.2. S.613. 